\title{
The Development of Higher Order Thinking Skill (Hots) Instrument Assessment In Physics Study
}

\author{
Merta Dhewa Kusuma ${ }^{(1)}$, Undang Rosidin ${ }^{(1)}$, Abdurrahman $^{(1)}$, Agus Suyatna ${ }^{(1)}$ \\ (1) Lampung University, Lampung, Indonesia
}

\begin{abstract}
TIMMS and PISA survey results illustrate that the indonesian student's ability to think scientifically is low. It is because of students are less trained in solving HOTS. Then, lack or unavailability the assessment instrument designed to train HOTS, so it is necessary to develop the assessment instrument of HOTS. Model adapt the model development of Borg \& Gall. The purpose of thisresearchare to determine the indicators and the effectiveness of the HOTS assessment instrument as assessment for learning for a high school students. The assessment instrument was developed based on HOTS indicators include the ability to analyze (C4), evaluate (C5), and create (C6). Results of the research are: (1) indicator of the ability to analyze (C4) which has been developed are ability to analysis of factual, conceptual, procedural, and metacognitive knowledge; (2) indicator of the ability to evaluate (C5) which has been developed are ability to evaluate of factual, conceptual, procedural, and metacognitive knowledge; (3) Indicator of the ability to create (C6) that has been developed are ability to create of conceptual, procedural, and metacognitive knowledge; (4) the HOTS assessment instrument as assessment for learning is effective to train student's HOTS and effective measure student's thinking skills in accordance with the level of each student's thinking.
\end{abstract}

Key Words: assessment, instrument, Indicator of Higher Order Thinking Skill (HOTS)

\section{Introduction}

Especially for higher students, they must not only have a lower order thinking (LOT), but also have to reach a higher order thinking (HOT). However, based on PISA which is reported by the Organization for Economic Co-Operation and Development (OECD), Indonesia is at 64 rank of 65 countries (OECD 2012). This result shows that most of Indonesian students still have low ability, if it is seen from cognitive aspect (knowing, applying, reasoning).

Beside that, student's achievements tend so decrease on all cognitive aspects that student's ability need to be increased, particularly reasoning aspect by teaching students to develope higher order thinking (Efendi, 2011: 393). It's because students should be able to make observations, ask questions, reason, and communicate what they have gained after receiving a lesson. In addition, a knowledge can not be transferred directly from teacher to student (Nuh: 2013).

According to Heong, et al(2011) higher order thinking is using the thinking widely to find new challenge. Higher order thinking demands someone to apply new information or knowledge that he has got and manipulates the information to reach possibility of answer in new situation. Brookhart (2010:5) states that higher-order thinking conceived of as the top end of the Bloom's cognitive taxonomy. The teaching goal behind any of the cognitive taxonomies is equipping students to be able to do transfer. "Being able to think" means students can apply the knowledge and skills they developed during their learning to new contexts. "New" here means applications that the student has not thought of before, not necessarily something uni-versally new. Higher-order thinking is conceived as students being able to relate their learning to other elements beyond those they were taught to associate with it.

To develop the ability to think critically, there are five lessons that can be taken, namely: (1) determine the learning objectives, (2) teach through inquiry, (3) practice, (4) review, refine and improve understanding, and (5) practice feedback and assess learning (Limbach \& Waugh, 2010).

It needs an assessment to see the development of higher order thinking. According to minister education and culture's regulation (permendikbud) No 53, 2015, the assessment of study result by educator is information or data collecting process about student's achievements in attitude aspect, knowledge aspect, and skill aspect which is done systematically to observe the process, study progress, and study result improvement by giving an assignment and evaluation of study result.

The principle and assessment have to increase student's study, and assessment is a valuable instrument to make teaching decision (Van de Walle, 2007: 78). In addition, Barnett \& Francis (2012: 209) states that the higher order thinking questions may encourage students to think deeply about the subject matter. So that the istrument assessment of higher order thinking can give stimulation as assessment for learning to develope student's higher order thinking. assessment for learning is used to improve the learning process, known as formative assessment (Weeden, Winter, and Broadfoot, 2002, p.13). According to Earl (2006: 7), assess-ment 
for learning is assessment that is designed to provide information for teachers to modify the learning activities, differentiate and understand the way students approach learning. In this study, to train high order thinking skills of students, assessment for learning is needed to improve learning in the classroom.

The problem in school is the questions used in cognitive instrument assessment which tend to test more on the memory aspect, meanwhile the questions that train student's higher order thinking skill are not quite available. From PISA survey result, indonesian children thinking ability are still considered low. One of the cause factors is that indonesian students do not trained much in solving contextual questions, demanding intellectual activity, argumentation and creativity in finishing it, where the questions are PISA characteristics questions which estimate HOTS. in addition, teachers have lack ability in developing instrument assessment towards HOTS, and not enough or so unavailable of the instrument assessment which specially designed to train HOTS, that the instrument assessment needs to be developed as assessment for learning to train student's higher order thinking.

To develop the ability to think critically, there are five lessons that can be taken, namely: (1) determine the learning objectives, (2) teach through inquiry, (3) practice, (4) review, refine and improve under-standing, and (5) practice feedback and assess learning (Limbach \& Waugh, 2010). According Krathworl (2002) indicators to measure the high-level thinking skills include: analyzing, evaluating, creating. Thus, HOTS is a thinking skills that not only requires the ability to re-member, but also other higher capabilities include the ability to analyze, evaluate, and create.

Schraw et al. (2011: 191) classifies bloom's thinking skill into two categories that is Lower Order Thinking Skills which consists of knowledge, understanding and application. Higher Order Thinking Skills which consists of analysis, synthetic and evaluation. Description and key word of each category can be seen in table 1 .

Table 1 Description and Key Word of Bloom's Taxonomy Revision

\begin{tabular}{|c|c|c|}
\hline CATEGORY & KEY WORDS & \\
\hline $\begin{array}{l}\text { Remembering: can the student recall or } \\
\text { remember the information? }\end{array}$ & $\begin{array}{l}\text { Mention the definition, imitate the pronunciation, state } \\
\text { the structure,pronounce, repeat, state }\end{array}$ & \multirow{3}{*}{$\begin{array}{l}\text { LOTS-Lower } \\
\text { Order Thingking } \\
\quad \text { Skill }\end{array}$} \\
\hline $\begin{array}{l}\text { Understanding : Can the students explain } \\
\text { the concept, principle, law or procedure? }\end{array}$ & $\begin{array}{l}\text { Classify, describe, explain the identification, placed, } \\
\text { report, explain, translate, paraphrased. }\end{array}$ & \\
\hline $\begin{array}{l}\text { Applying : Can students apply their } \\
\text { understanding in new situation? }\end{array}$ & $\begin{array}{l}\text { Choosing, demonstrating, acting, using, illustrating, } \\
\text { interpreting, arranging schedule, making sketch, } \\
\text { solving problem, writing }\end{array}$ & \\
\hline $\begin{array}{l}\text { Analyzing: can students classify the sections } \\
\text { based on their difference and similarity? }\end{array}$ & $\begin{array}{l}\text { Examining, comparing, contrasting, distinguish, doing } \\
\text { discrimination, separating, test, doing experiment, } \\
\text { asking }\end{array}$ & \multirow[t]{3}{*}{$\begin{array}{l}\text { HOTS-Higher } \\
\text { Order Thingking } \\
\quad \text { Skill }\end{array}$} \\
\hline $\begin{array}{l}\text { Evaluating: can students state either good or } \\
\text { bad towards a phenomenon or certain object? }\end{array}$ & $\begin{array}{l}\text { Giving argumentation, defending, stating, choosing, } \\
\text { giving support, giving assessment, doing evaluation }\end{array}$ & \\
\hline $\begin{array}{l}\text { Creating: can students create a thing or } \\
\text { opinion? }\end{array}$ & $\begin{array}{l}\text { Assemble, change, build, create, design, establish, } \\
\text { formulate, write. }\end{array}$ & \\
\hline
\end{tabular}

In Bloom's taxonomy, there is only known one cognitive domain but in Anderson and Krathwohl's taxo-nomy become two dimensions. First dimension is Knowledge Dimensionand Cognitive Process Dimension. Anderson and Krathwohl's two dimensions perspective for higher order thinking and classification of its operational verbs can be described in table 2 .

Table 2 Bloom's taxonomy of dimentional revision and Examples of operational verbs for higher order thinking

\begin{tabular}{|c|c|c|c|}
\hline \multirow{2}{*}{ The Knowledge Dimension } & \multicolumn{2}{|c|}{ The Cognitive Process Dimension } \\
\cline { 2 - 4 } & $\begin{array}{c}\text { C4 } \\
\text { analyze }\end{array}$ & $\begin{array}{c}\text { C5 } \\
\text { evaluate }\end{array}$ & $\begin{array}{c}\text { C6 } \\
\text { create }\end{array}$ \\
\hline Factual Knowledge & Making structure, classifying & comparing, correlating & joining \\
\hline Conceptual Knowledge & explain, analyze & Examine, interpret & planning \\
\hline Procedural Knowledge & distinguish & conclude, resume & Arrange, formulate \\
\hline Metacognitive Knowldege & create, find & Make, assess & realization \\
\hline
\end{tabular}

(Anderson and Krathwohl, 2001)

The development of physics instrument assessment in this research involves knowledge dimension and cognitive dimension as it is classified in table 2 above. The purpose of the development of instrument assessment is to know the effectiveness indicator of isntrument assessment towards HOTS as assessment for learning for higher student's on physics learning in static fluid material. 


\section{Methodology Research}

This research is a development research. The developed product is instrument assessment to train student's higher order thinking (HOTS). development type is adapted from Borg and Gall's type which consists of 10 development steps. However in this research is used 7 steps only, which consist of: 1) research and collect the information, 2) planning, 3) the development of early product, 4) limited try out, 5) the revision of early product, 6) field try out, and 7) the revision of final product

1. Research and collect the data

Research and collect the information are done based on relevant theory examination.

2. Planning step

The planning step in this research is as follow: 1) arrange the indicator of instrument assessment towards HOTS, questions drill, test questions of HOTS, score and assessment column, 2) determine the instrument validity through the helping of physicist's test to validate the instrument made, 3) do instrument revision based on validastor's suggestion, 4) do limited try out, 5) determine distinguishing power, difficulty level, and reliability of question items, 6) do field try out, 7) do product revision based on the result of try out.

3. Development of early product step

a. Determine the purpose of instrument assessment that is to train high school student's higher order thinking (HOTS)

b. Arrangement of instrument assessment form. Instrument assessment which developed is questions drill of HOTS, multiple choice questions and essay, and answer key based on the indicator of KD and HOTS.

c. Validation of HOTS question items. Valid or deserve questions used will be measured based on lecturer's assessment. Data collecting instrument used is by questionnaire validation

d. Revision of question items and arrangement of questions. Result of validation by validator which has been got is used for revising developed question items. Then, revised question items are arranged into instrument test which will be tried out such as multiple choice and essay

4. Limited try out

Then, Instrument test which has been arranged is used to do limited try out. Result of limited try out that will determine how the question parameter developed is, such as reliability, distinguishing power, and difficulty level.

Limited try out is done in Senior High School Number 1 Kotabumi with 24 number of samples.

5. Revision of early product

Then, Questions which have been known reliability, distinguishing power and difficulty level are arranged into early product which are used for field try out.

6. Field try out

Then, Instrument assessment which has been revised is tried out in 3 Senior High School in Lampung. the number of samples used is one class for each school with the number of students shown in table 3 .

Table 3 the number of students used in the research

\begin{tabular}{|c|c|c|}
\hline No & School & Number of students \\
\hline $\mathbf{1}$ & SMA Negeri 1 Kotabumi & 40 \\
\hline $\mathbf{2}$ & MA Muhammadiyah Abung Kunang Kotabumi & 25 \\
\hline $\mathbf{3}$ & SMA Al-Anshor Way Bayas Gadingrejo Pringsewu & 30 \\
\hline \multicolumn{2}{|c|}{ total } & 95 \\
\hline
\end{tabular}

The result of field try out is done to see the instrument assessment which has been developed as assessment for learning for students in training their HOTS. Through instrument assessment of HOTS, students can be categorized based on their thinking ability. HOTS categories are shown in table 4.

Table 4 category level of higher order thinking

\begin{tabular}{|c|c|}
\hline Student's mark & Level of students' higher order thinking \\
\hline $100-76$ & excellent \\
$75-51$ & good \\
$50-26$ & enough \\
$25-1$ & poor \\
\hline
\end{tabular}

(adapted from Lewy, 2009)

7. Revision final product

Then, After doing field try out, is doing HOTS arrangement questions which can examine student's HOTS indeed. The the arrangement questions are tried out again to see if it is really effective in measuring student's HOTS. 


\section{Result And Discussion}

The development of early step made for about 15 multiple choice questions, and 15 essay. Then, the test of validation is done on the questions by the expert of test. Validation score which got is $81 \%$ with valid criterion. Next, limited try out is done to know reliability, difficulty level and distinguishing power of HOTS questions. The try out questions are consist of 15 multiple choice and 15 essay. The result of limited try out cab be seen in table 5 and table 6 .

Table 5 the result of reliability test of HOTS questions

\begin{tabular}{|c|c|c|}
\hline Type of questions & score $r$ & criterion \\
\hline multiple choice & 0,74 & high \\
\hline essay & 0,71 & high \\
\hline
\end{tabular}

Table 6 the result of difficulty level and distinguishing power test of multiple choice and essay of HOTS questions

\begin{tabular}{|c|c|c|c|c|c|c|c|c|}
\hline \multirow{3}{*}{$\begin{array}{l}\text { No. } \\
\text { questi } \\
\text { ons }\end{array}$} & \multicolumn{4}{|c|}{ Multiple choice questions } & \multicolumn{4}{|c|}{ Essay questions } \\
\hline & \multicolumn{2}{|c|}{ Difficulty level } & \multicolumn{2}{|c|}{ Distinguishing power } & \multicolumn{2}{|c|}{ Difficulty level } & \multicolumn{2}{|c|}{ Distinguishing power } \\
\hline & score & criteria & score & criteria & score & criteria & score & criteria \\
\hline 1 & 0,70 & medium & 0,33 & accepted & 0,58 & medium & 0,33 & accepted \\
\hline 2 & 0,92 & easy & 0,33 & accepted & 0,48 & medium & 0,41 & accepted \\
\hline 3 & 0,45 & medium & 0,33 & accepted & 0,33 & medium & 0,33 & accepted \\
\hline 4 & 0,67 & Medium, & 0,33 & accepted & 0,39 & medium & 0,33 & accepted \\
\hline 5 & 0,46 & medium & 0,5 & accepted & 0,51 & medium & 0,2 & revised \\
\hline 6 & 0,75 & easy & 0,83 & accepted & 0,55 & medium & $-0,04$ & rejected \\
\hline 7 & 0,5 & medium & 0,83 & accepted & 0,51 & medium & 0,25 & revised \\
\hline 8 & 0,29 & difficult & 0,83 & accepted & $\mathbf{0 , 5 5}$ & medium & 0,16 & rejected \\
\hline 9 & 0,70 & medium & 0,5 & accepted & 0,61 & medium & 0,37 & accepted \\
\hline 10 & 0,70 & medium & 0,83 & accepted & 0,43 & medium & 0,33 & accepted \\
\hline 11 & 0,70 & medium & 0,83 & accepted & 0,59 & medium & 0,2 & revised \\
\hline 12 & 0,79 & easy & 0,33 & accepted & $\mathbf{0 , 6 1}$ & medium & 0,16 & rejected \\
\hline 13 & 0,70 & medium & $-0,33$ & rejected & 0,54 & medium & 0,41 & accepted \\
\hline 14 & 0,92 & easy & 0,33 & accepted & 0,42 & medium & $\mathbf{0}$ & rejected \\
\hline 15 & 0,96 & medium & 0,17 & rejected & 0,55 & medium & 0,16 & rejected \\
\hline
\end{tabular}

Then, Multiple choice and essay questions which have known the parameter, are arranged into instrument product which are used for field try out. Instrument assessment that has been arranged is used in field try out as assessment for learning to train students HOTS. field try out is done for 4 times meeting for each high school. 3 first meetings are done to train student's HOTS. through this 3 meetings, student's thinking ability will be trained by using instrument assessment which has been developed. The instrument assessment contains the indicator that is used to train student's HOTS. Meanwhile, one last meeting is used to test the questions totally to know the effectiveness of instrument test developed whether it is effective in measuring student's HOTS based on their thinking ability or not. Every meeting discusses different topic. In this meeting, it happens learning and teaching process in order to make the students understand the topic so that they can do HOTS questions which have been arranged as assessment for learning. After doing the learning, students are given some multiple choice and essay questions to train their thinking ability. The given questions contain the indicator which can train student's HOTS. the indicator descriptions used to train student's HOTS in order to reach development purpose of HOTS instrument assessment are shown in table 7.

Table 7 indicator descriptions of instrument assessment in training student's HOTS

\begin{tabular}{|c|c|c|c|}
\hline No & $\begin{array}{c}\text { The purpose of student's } \\
\text { achievements }\end{array}$ & Questions of indicator & $\begin{array}{l}\text { Cognitive dimension } \\
\text { and knowledge }\end{array}$ \\
\hline 1 & $\begin{array}{l}\text { Investigate pressure } \\
\text { concept in daily life }\end{array}$ & $\begin{array}{l}\text { a. Conclude the magnitude pressure in certain altitude / } \\
\text { depth } \\
\text { b. Explain the correlation of ice skating shoes design with } \\
\text { pressure concept } \\
\text { c. Show which thing has bigger pressure towards pressure } \\
\text { d. Show big comparison of pressure on two different size } \\
\text { e. Elocks } \\
\text { f. Design a simple experiment to prove the existence of air } \\
\text { pressure differentiation. }\end{array}$ & $\begin{array}{l}\mathrm{C} 4 \mathrm{PM} \\
\mathrm{C} 4 \mathrm{PK} \\
\mathrm{C} 5 \mathrm{PF} \\
\mathrm{C} 5 \mathrm{PF} \\
\mathrm{C} 5 \mathrm{PF} \\
\mathrm{C} 6 \mathrm{PM}\end{array}$ \\
\hline 2 & $\begin{array}{l}\text { Investigate the prime law } \\
\text { of hydrostatics }\end{array}$ & $\begin{array}{l}\text { a. Analyze the magnitude of hydrostatic pressure in each } \\
\text { hole on a medium } \\
\text { b. Conclude the principle of hydrostatic pressure on the }\end{array}$ & $\begin{array}{l}\text { C4 PP } \\
\text { C4 PM }\end{array}$ \\
\hline
\end{tabular}




\begin{tabular}{|c|c|c|c|}
\hline & & $\begin{array}{l}\text { medium which has the same depth point } \\
\text { c. Analyze the altitude of liquid if } 2 \text { different liquids put } \\
\text { into a communicating vessel } \\
\text { d. Give description about the magnitude of hydrostatic at } \\
\text { the bottom of dam because of gravitation influence }\end{array}$ & $\begin{array}{l}\text { C6 PP } \\
\text { C6 PK }\end{array}$ \\
\hline 3 & $\begin{array}{l}\text { Determine the energy in } \\
\text { pascal law }\end{array}$ & $\begin{array}{l}\text { Determine the magnitude of energy given so that a car can be } \\
\text { lifted (pascal law application) }\end{array}$ & C5 PF \\
\hline 4 & $\begin{array}{l}\text { Investigate floating case, } \\
\text { flying and drowning in } \\
\text { archimedes law }\end{array}$ & $\begin{array}{l}\text { a. Determine the magnitude of object part which appears } \\
\text { on liquid surface if the object floats (archimedes law } \\
\text { application) } \\
\text { b. Analyze the phenomenon in daily life correlating to } \\
\text { archimedes law } \\
\text { c. Conclude the object position based on object density if it } \\
\text { puts into the liquid } \\
\text { d. Evaluate the principle of submarine } \\
\text { e. Conclude the appropriate statement which has the } \\
\text { f. Examine the influence of liquid density towards floating, } \\
\text { g. Formulate the similarity which has the correlation to the } \\
\text { flying and drowning event of an object } \\
\text { comparison of block density with liquid as well as the } \\
\text { magnitude of block density }\end{array}$ & $\begin{array}{l}\text { C4 PF } \\
\text { C4 PF } \\
\text { C5 PM } \\
\text { C5 PP } \\
\text { C5 PM } \\
\text { C6 PP }\end{array}$ \\
\hline
\end{tabular}

The result of field try out is done to see the instrument assessment which has been developed as assessment for learning for student's in training their HOTS. through instrument assessment of HOTS, students can be categorized based on higher order thinking appropriate with each category seen in table 8 .

Table 8 student's higher order thinking

\begin{tabular}{|c|c|c|}
\hline category & number & percentage \\
\hline excellent & 8 & $8,4 \%$ \\
\hline good & 50 & $52,6 \%$ \\
\hline enough & 32 & $33,6 \%$ \\
\hline poor & 5 & $5,4 \%$ \\
\hline total & $\mathbf{9 5}$ & $\mathbf{1 0 0} \%$ \\
\hline
\end{tabular}

The result of this research shows that the instrument of HOTS which has been developed can help students in training their higher order thinking ability as assessment for learning. Based on field try out to train student's HOTS, it can be seen that students with HOTS ability and good category are amount to 50,2\%. Thus, instrument assessment of HOTS which has been developed is so effective in training students to have good HOTS, that instrument assessment can be used as assessment for learning for students. This result is parallel with the research done by Treagust, et al (2001) about the using of assessment as the guidance in teaching the science understanding towards high school students. The result got in this research shows that learning by using scoring sheet as assessment for learning can increase student's ability in science learning. Therefore, the using of HOTS instrument assessment as assessment for learning which has been developed can train the student's thinking ability that mostly are in good ability of HOTS category. After students classified based on their own HOTS category, then the arrangement of question is totally done and given back to them to see the effectiveness of instrument test which has been developed whether it can measure student's HOTS based on the criteriarequired or not. The result of field try out totally for each category can be seen in table 9 .

Table 9 the result of instrument try out totally

\begin{tabular}{|c|l|c|l|}
\hline Early average mark & \multicolumn{1}{|c|}{ category } & Final average mark & \multicolumn{1}{c|}{ category } \\
\hline $\mathbf{7 9 , 2 5}$ & excellent & 82,37 & excellent \\
\hline $\mathbf{6 0 , 5 2}$ & good & 66,71 & good \\
\hline $\mathbf{4 3 , 8 4}$ & enough & 48,8 & enough \\
\hline $\mathbf{2 2}$ & poor & 24,6 & poor \\
\hline
\end{tabular}

Table 9 shows that students who are categorized into higer order thinking criteria, excellent, good, enough and poor have the same criteria when they are tested again through HOTS questions totally. Then, the instruments of developed HOTS test are considered effectively in measuring student's HOTS based on their 
own ability level. The result of this instrument assessment effectiveness is shown in table 9 that is interpreted in picture 1 .

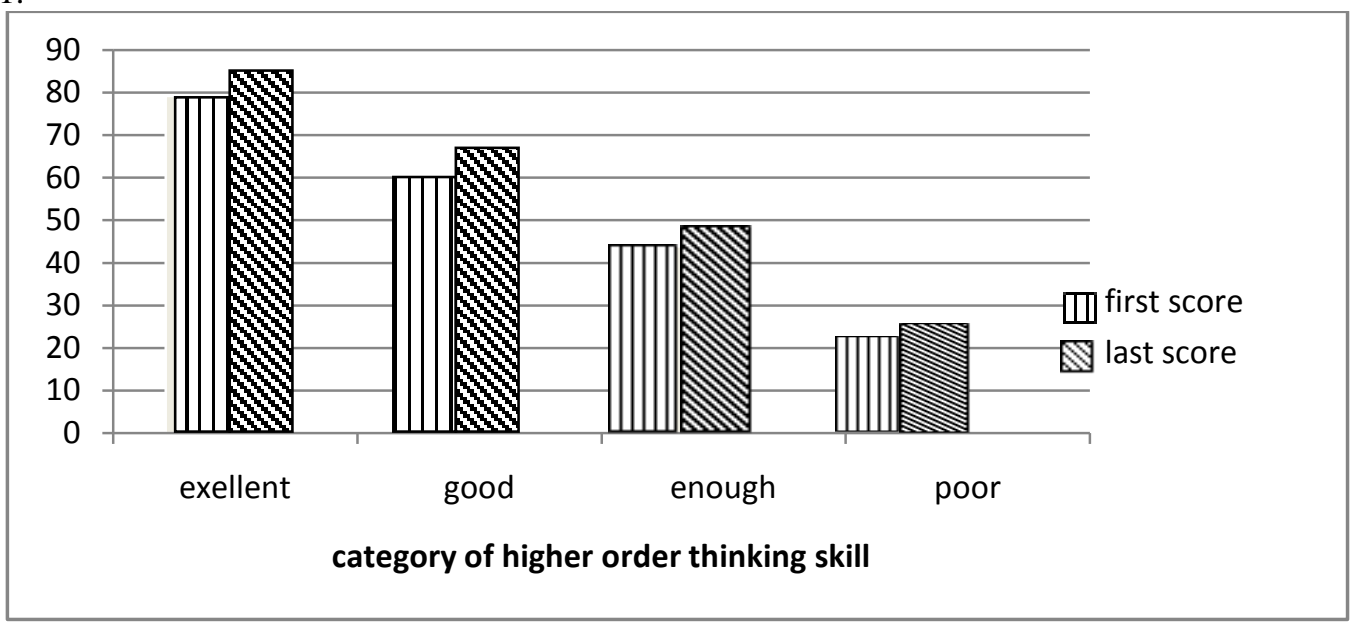

Picture 1early average mark (3 first meetings) and final average mark (1 last meeting)

picture1 shows that students with excellent HOTS ability, still have excellent HOTS ability after doing HOTS questions again. It is the same as the students with good HOTS ability, they still have good HOTS ability, students with enough HOTS ability, they still have enough HOTS ability, and students with poor HOTS ability, they still have poor HOTS ability this result shows that the instrument assessment of developed HOTS is effective in measuring student's HOTS based on their thinking ability. This result of research is parallel to the result of research done by Abosalem (2016) about assessment technique on student's higher order thinking ability which shows that by using HOTS assessment, it will help students in decreasing and evaluating their thinking ability such as using either multiple choice test or essay test. Treagust, et. al (2001) investigated the use of Assessment as a Guide in Teaching for Understanding shows that learning to use the assessment sheet as assessment for learning can enhance student's skills in science. Using of assessment instruments as assessment for learning is needed to train student's thinking skills. It also agrees with the study by Klenowski (2009) on Assessment for Learning revisited: an Asia-Fasific perspective. The results obtained showed that assess-ment for learning is proven to help develop student's thinking skills.

In this case, the using of instrument assessment of HOTS is one of alternatives for teachers to train and determine student's HOTS level. By doing HOTS questions,students can give suitable answers based on their thinking ability, so that teachers know how good the students thinking ability is.

\section{Conclussions}

The conclussions of this research stated that there had been developed an instrument assessment of HOTS with HOTS indicators in static fluid material based on cognitive dimension process in form of analysing ability (C4), evaluating (C5), and creating (C6), as well as knowledge dimensions in form of factual knowledge, conceptual procedure, and metacognitive.

The indicators of analysing ability (C4) which have been developed are knowledge analysing ability $(\mathrm{PF})$, conseptual knowledge analysis (PK), procedural knowledge analysis (PP), and metacognitive knowledge analysis (PM). The indicators of the evaluation of ability (C5) which have been developed are the ability of factual knowledge evaluation (PF), conceptual knowledge evaluation (PK), procedural knowledge evaluation (PP), and metacognitive knowledge evaluation (PM).

The indicators of creating ability (C6) which have been developed are conceptual knowledge creating ability (PK), creating procedural knowledge (PP), and creating creating metacognitive knowledge (PM).

Based on the result of research, instrument assessment of HOTS as assessment for learning is effective to train student's HOTS as well as effective in measuring student's thinking ability based on each student's HOTS level. My special gratitude for the research institution and the dedication of Lampung University which have supported the finance of this research.

\section{Bibliographies}

[1]. Abosalem, Yousef. 2016.Assessment Techniques and Students Higher-Order Thinking Skills. International Journal of Secondary Education, 4 (1): 1-11. http://www.sciencepublishinggroup.com/j/ijsedu.

[2]. Anderson, L.W., and Krathwohl, D.R. 2001. A Taxonomy of Learning, Teaching, and Assessing: A Revision of Bloom's Taxonomy of Educational Objectives. New York Longman.

[3]. Barnett, J. E and Francis, A.L. 2012. Using higher order thinking questionsto foster critical thinking: a classroom study. Educational Psychology: An International Journal of Experimental Educational Psychology. 
[4]. Borg, W. R. \& Gall, M.D. 1983. Educational researcher: An introduction, (7th ed.). United States : Pearson education, Inc

[5]. Brookhart, S. M. (2010). How to Assess High-er Order Thinking Skills in Your Class-room. Alexandria: ASCD

[6]. Earl, L. 2006. Assessment - a powerful lever for learning. Brock Education. 16(1), 2006.

[7]. Efendi, Ridwan. 2010. Kemampuan Fisika Siswa Indonesia dalam TIMSS. Prosiding Seminar Nasional Fisika 2010 ISBN : $978-$ 979-98010-6-7

[8]. Heong, Y. M.,Othman, W.D.,Md Yunos, J., Kiong, T.T., Hassan, R., \& Mohamad, M.M. 2011. The Level of Marzano Higher Order Thinking Skills Among Technical Education Students . International Journal of Social and humanity, Vol. 1,No. 2, July 2011, 121125

[9]. Klenowski, V. 2009. Assesment for Learning revisited: an Asia-Fasific perspective. Assesment in Education: Principles, Policy, Practice. Vol. 16, No 3, November 2009, 263-268.

[10]. Krathwohl, D. R.2002. A revision of Bloom's Taxonomy: an overview - Theory Into Practice, College of Education, The Ohio State University Pohl. 2000. Learning to think, thinking to learn: ( tersedia di www.purdue.edu/geri diakses 22 Februari 2016)

[11]. Lewy, Zulkardi, \& N Aisyah. 2009. Pengembangan Soal untuk Mengukur Kemampuan Berpikir Tingkat Tinggi Pokok Bahasan Barisan dan Deret Bilangan di Kelas IX Akselerasi SMP Xaverius Maria Palembang. JURNAL Pendidikan Matematika (3) : 15-28.

[12]. Limbach, B \& Waugh, W. 2010. Developing Higher Level Thinking. Journal of Instructonal Pedagogies. p: 1-9

[13]. OECD. 2012. PISA 2011: Science competencies for tomorrow world volume 1: Analysis. Rosewood. Drive: OECD

[14]. Nuh, Mohammad. 2013. Peraturan Menteri Pendidikan dan Kebudayaan Republik Indonesia Nomor $81 a$ Tahun 2013 Tentang Implementasi Kurikulum

[15]. Permendikbud. 2015. Peraturan Menteri Pendidikan dan Kebudayaan Republik

[16]. Indonesia nomor 53 tahun 2015, tentang Penilaian hasil belajar Pendidik pada pendidikan dasar dan pendidikan menengah.

[17]. Schraw, Gregory, Robinson, DH. 2011. Assessment Of Higer Order Thinking Skillss. America: Information Age Publishing.

[18]. Treagust. DF, R. Jacobowitz, JL. Gallagher, and Parker. 2001. Using Assesment as a Guide in Teaching for Understanding: A Case Study of a Middle School Science Class Learning about Sound. Science Education 85 (2), 137-157, 2001.

[19]. Van de Walle, J. A. 2007. Elementary and middle schoolmathematics: teaching developmentally, (6th ed.). United Statesof America: Pearson Education, Inc.

[20]. Weeden, P., Winter, J., \& Broadfoot, P. 2002. Assessment: What's in it for schools? London: Mohamad Routledge Falmer. 